\title{
Information Systems as an Infrastructure for University Research Now and in the Future: Their Role in Helping Public Universities Cope with Financial and Political Stress
}

David Shulenburger, Senior Fellow, Association of Public and Land Grant Universities and Professor Emeritus, University of Kansas

$\mathrm{D}$ ata come at us rapidly from nearly every quarter and demand to be analyzed. High speed, high capacity computers, blindingly fast networks and massive storage capability, huge quantities of digitally searchable text and considerable expertise will be required to deal with it all.

According to George Dyson, the data universe grows at 5 trillion bytes a second. Just as a seemingly inert lump of matter disguises the intricate physics and geometry within it, the flood of data contains patterns that we will never know of unless we have the capacity to fully understand them. Where did the stock market's "flash crash" of May 2010 come from? Does "junk" DNA actually play a key role in biological functioning? Do patterns of word usage and grammar from the 1700s suggest deeper understanding of the physical world than we heretofore imagined?

Ubiquitous connectivity, inexpensive sensors, falling storage costs have made the analysis of "big data" mandatory. Examples of big data sets that may reveal both surface and hidden meanings to us are:

- Routinely captured and shared medical records data bases

- Genome: for millions of people at an increasingly modest cost

- Human Biome: 10,000+ organisms inhabit the human body
- Culturomics: Over 15 million books have been digitized. Word frequency, birth and propagation of ideas, celebrity, demonization, taboos, commerce, business cycles, etc., etc., etc.

- Google with 10 billion web pages, email, texts, blogs, etc.

- Facebook and other "social media"

- Securities transactions, on-line financial transactions

The future requirements for an information infrastructure to support research within a university are not hard to discern and are reasonably well understood. In the listing below, I add only one novel characteristic, affordability.

I come from a long history of public

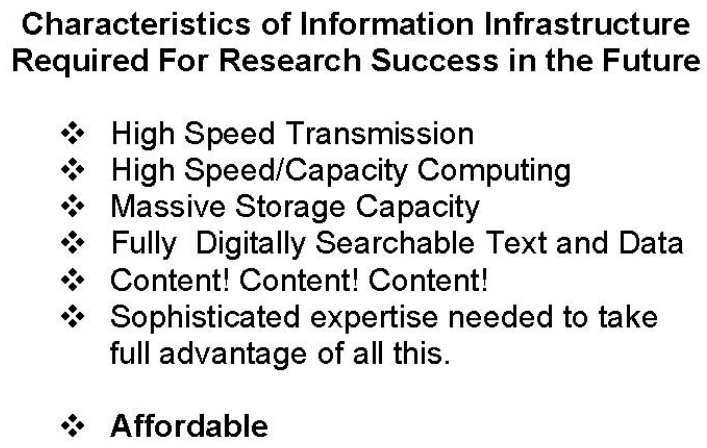


university involvement, deep at one university, the University of Kansas, and broad, involving all the 217 public research member universities and systems that belong to the Association of Public and Land-grant Universities (APLU). The perspective brought by knowledge of that set of universities causes me to take this paper in a direction that recognizes their economics. And that leads me to ask "Can public universities afford to compete in this future?"

The Declining Economic Fortunes of Public Universities

Public universities operate at a distinct disadvantage relative to our competitors in both private universities and in the corporate world. Mark Emmert, then President of the University of Washington, and a keen observer of the economic damage being done to the "system" of public universities independently funded by the fifty states observed: "[public research universities have] evolved into a critical national asset...we could see 50 different independent decisions made in 50 different states and the result would be a national tragedy!" Former President of the University of Vermont, Mark Fogel, on examining the same terrain, chillingly summed up the feeling of major public university presidents, "We are haunted by the specter that our enterprise has seen its best days ..."

Briefly, the primary financial problem of public universities is that their major patrons, the 50 states, have been defunding them on a per student basis for last three decades as Figure I aptly illustrates. While public universities have been able to replace lost educational appropriations with added tuition dollars, the source from which funds are derived has subtle effects on how they are spent by university officials. I shall have more on the effects of source on distribution later. Figure I includes funding data for all public higher education from community colleges to the most sophisticated graduate universities. Segregating the data for the public universities in the Carnegie classifications "very high research universities" and "high research universities" in Figure II demonstrates that both categories of research universities have suffered from the cuts. Since 2007 real appropriations have fallen at least $10 \%$ for both categories.

I suspect that it will be quite some time, if ever, before state per student funding of public universities returns to the levels of two decades ago. There are many reasons for this judgment but a sufficient reason is that the competition for scarce state resources has grown very intense. A major claimant for such resources in every state has been the federally-mandated state share of Medicaid funding. Figure III shows that state funding for Medicaid and higher education were close to equal in 1987 but Medicaid expenditure has grown by a factor of 5.3 in the intervening years while higher education grew by only 1.3.

Higher education has a very big stake in the 2012 presidential election, as the debate concerning public funding of health care, illustrated in Figure III, makes clear. Other competitors for state funding include prisons, pension funding and infrastructure. Many believe that the growing private goods nature of higher education has led state legislators to conclude that it should be funded by students rather than taxpayers. Whatev- 
er the argument, few informed observers believe that state subsidy of higher education will grow quickly in the near future.

The Growing Funding Advantage of Private Universities

While state funding has declined, tuition at public research universities has increased but only by enough to slightly more than offset the loss of appropriated funds. Private research universities charge significantly larger tuitions than public universities and have far larger endowments per student. The result is that their available funds per student are far greater than those of public universities. As a result private research universities spend more than 2.3 times as much per FTE student on educational and general expenditures as do public universities. That multiple has been maintained over time (Figure IV). This higher level of expenditure permits private universities to acquire the quality and volume of resources they desire. Such resources include faculty and staff. As a result faculty salaries at public research universities have fallen from near parity with those at private research universities in the 1970s to around $80 \%$ of their level today (Figure V).

Similarly, private research universities have increased their instructional staffing per student more than public universities. In 2007 the level of staffing per students at private research universities reached $120 \%$ of the level of public research universities (Figure VI).

The relatively smaller funding of public research universities in and of itself reduces their ability to compete with the privates. But the increasing proportion of funding that comes from tuition in the publics and the decreasing proportion coming from tuition in private institutions exert subtle effects on the choices administrators make about where to spend institutional resources (Figure VII).

As tuition increases as a proportion of E\&G expenditure, relatively more resources are spent on activities that are seen as directly benefiting undergraduate students and relatively less on activities that benefit graduate students or research. A prime example of this can be observed in expenditures on research libraries. The library budget as a percent of total university E\&G falls more in public than in private universities as the proportion of the education and general budget derived from tuition increases. This effect probably generalizes to other areas of the budget, including research.

Another explanatory factor for the difference in level and trend of E\&G expenditures on libraries is the differential in academic program makeup at public and private research universities. Public universities have approximately $21 \%$ of their students in graduate programs while private universities have $49 \%$. Given the greater need for access to the research portion of the collection by graduate students, it is to be expected that private universities would spend the larger proportion of their funds on libraries. Similarly, the pressure from undergraduates to spend monies on programs directly benefiting undergraduate students would be greater at public research universities. Thus, the "tune" is called not only by the increasing proportion of the budget derived from tuition, but from the relative pro- 
portions of graduate and undergraduate students (Figure VIII).

Another source of relative disadvantage comes from the larger subsidy that public universities provide to federal research than do private universities. This probably arises because public universities understand that they are at a disadvantage relative to private universities in the competition for federal grants and subsidize their research activities more in order to make their proposals relatively more attractive to funding agencies (Figure IX).

The strategy apparently works, for public universities have gained an increasing share of federal research grants over time as the subsidy for research they conduct was increased. But the burning question is whether subsidy of any size can compensate in the longterm for the public university's rapidly falling real state subsidy and increasing funding from a budgetary source that is less compatible with funding of research (Figure X).

Growing Research Funding Success of Industry and Government Labs

But both private and public universities have competition for funding from other sources. Industry, government labs and non-profits each have increased their share of the federal research dollar since 2002. Thus, our thinking about public university competitiveness for research has to be broadened beyond the private university competitors (Figure XI).

A Plausible Empirical Explanation for the Growing Disadvantage of Public Research Universities

Is there a coherent argument that explains why public university subsidy from the states has fallen and why more of the research dollar is flowing away from universities? I think there is and it has recently been articulated in an article by Gordon Gauchata of the University of North Carolina. ${ }^{1}$ Gauchata examines polling data of the American citizenry and finds:

- Public trust in science has not declined since the 1970s except among conservatives and those who frequently attend church,

- That there is negligible evidence for the cultural ascendency thesis, which suggests that trust in science will increase over time. Nor do poll results support the alienation thesis that predicts a uniform decline in public trust in science,

- Polling results are consistent with claims of the politicization thesis and show that conservatives experienced long-term group-specific declines rather than an abrupt cultural break,

- Educated conservatives uniquely experienced the decline in trust in science. (Figure XII)

Gauchata found that the public defines "what science is" in three distinct ways:

(1) As an abstract method (e.g., replication, empirical, or unbiased);

(2) As a cultural location (e.g., takes place in a university or is practiced by highly credentialed individuals); and

(3) As one form of knowledge among other types such as commonsense and religious tradition.

Conservatives were far more likely to define science as knowledge that should conform to common sense and religious tradition. When examining a 
series of public attitudes toward science, conservatives' unfavorable attitudes are most acute in relation to government funding of science and the use of scientific knowledge to influence social policy. Conservatives thus appear especially averse to regulatory science, defined here as the mutual dependence of organized science and government policy

Gauchata draws on the analysis of Lave, Mirowski and Randals ${ }^{2}$ to tie this research to the rise of neoliberal science management regimes since 1980, particularly the insistence on the commercialization and privatization of knowledge that has created substantive shifts in the organization and practice of science. Perhaps the most obvious shift is the rollback of government funding for, and organization of, public research universities. (Underlining is mine) He continues that the changes in the organization of science include:

(1) Increased government outlays to private corporations rather than universities;

(2) Intellectual property rights restricting public access to scientific knowledge; and

(3) Reversal of the postwar trend of viewing teaching and research as mutually reinforcing activities.

Gauchata's work neatly fits with the facts I observe. Federal research money is flowing differentially toward private corporations. The State subsidy to public universities has been reduced over time. The amendment of the copyright law overtime clearly has had the effect of restricting public access to scientific knowledge. Finally, the conservative resistance toward openly teaching some scientific findings are particularly rele- vant when we consider global climate change-and growing public skepticism toward that problem-- or when we consider the development of genomics and its implications for private interests.

I do not exclude explanations other than Gauchata's for the state of public universities and the distribution of research funding. I cite his explanation because it is consistent with the facts I observe. It seems to me that universities are relatively powerless to change the balance of power in governmental bodies between conservative and less conservative members; we must work with what we have. The relevant question is, "How do we as public universities acquire or acquire access to the information infrastructure that will enable us to maintain or improve our position in research, especially funded research, despite our financial weakness?"

\section{What Can be Done to Improve the} Research Competitiveness of Public Research Universities?

Many of the techniques used to enhance university research competitiveness are beyond the scope of this inquiry, which is limited to questions of information infrastructure. Clearly, public universities can and should continue proven techniques such as focusing their research investment in promising areas of research so that their grant funding possibilities will be enhanced and hiring accordingly.

Similarly, implementing each of the ten recommendations of the National Research Council's June 2012 report, $\underline{\mathrm{Re}-}$ search Universities and the Future of America, would clearly improve the prospects of public universities. Implementation of recommendations 1, 2, 6, 7 
and 10 would reduce or help public universities better cope with the financial disparities between public and private universities but implementation of all 10 recommendations would be of much benefit to all research universities. None of the recommendations directly address the information infrastructure topic of this inquiry but several of them would provide additional funding or administrative flexibility that might address problems in this area (Figure XIII).

Public Access to Information Infrastructure as a Means of Preserving and Strengthening Public Research University Competitiveness

What I recommend to address the information infrastructure needs is for public universities to promote the development of mechanisms and patterns of thought and behavior that enable sharing among all actors of the information infrastructure vital to the research enterprise. I am not advocating that public research universities form a collective and share among themselves. If they were to form a collective that excludes others, they would ensure only a shared poverty, not access to sufficient information infrastructure resources to make them competitive. Many of the information infrastructure resources public universities need are available to those who have infrastructure wealth, the private universities, private enterprise and the federal government.

Interestingly, what I spell out here as good for public research universities is also good for society. No less a visionary than Isaac Newton saw this: "If I have seen further it is by standing on the shoulders of giants." 3 Newton's giants reside in public universities and private universi- ties throughout the world as well as in government laboratories, the private labs of individual tinkerers and in industry. Leading the effort to keep the "shoulders of giants" available as a platform for all despite the resources that are available is essentially the role I foresee for public universities. They will be a major beneficiary.

But directly to the relevant point, the research of Furman and Stern into factors that led to increased citation, patents and diffusion of research reached this conclusion, "Overall, the ability of a society to stand on the shoulders of giants depends not only on generating knowledge, but also on the quality of mechanisms for storing, certifying and accessing that knowledge." 4 The mechanisms for storing and accessing knowledge are the core of information infrastructure.

Elias Zerhouni's (former NIH Director) vision of the ideal future of medical research involved creating the conditions/building the systems in which all research studies, all genome structures, all chemical information, all data sets, etc., were placed freely available on-line so that connections that an individual scientist may never encounter by reading the literature become discoverable. ${ }^{5}$ He fervently believes that such a system would dramatically enhance the productivity of science and set about creating a set of systems at NIH that would produce that end. The scientific literature; genome, tissue and whole organism data sets and repositories; and the research data bases that grew from his vision at NIH are precisely the kind of publicly available information infrastructure resources that enable public universities to 
compete with private universities, government labs and private industry and that also permit all researchers, wherever they are housed, to be more productive.

Finally we must recognize that the massive amount of knowledge that we have amassed and are adding to daily requires special storage and access conditions if they are to be truly available to researchers. Robert Merton foresaw this nearly 50 years ago when he said, "Perhaps no problem facing the individual scientist today is more defeating than the effort to cope with the flood of published scientific research, even within one's own narrow specialty. ${ }^{6 "}$ The thousands of articles that might have been available on a given subject then are an exponential multiple of that number now. Unless scientific literature, patents, data sets, etc., are stored in a digital form, accessible and readable by computers, they are not truly accessible.

The major forms of public access discussed below are:

I. Public Access To Scholarly Research

A. Public Access to Federal and Foundation Funded Research

B. Public Access Deposit Requirements by Universities

C. Open Access Journals

D. Digital Repositories by Universities, Disciplinary Societies

II. Open Research Data

III. Open Research Organisms and Materials

IV. Open Access to High Speed/ Capacity Computing

V. Open Access to High Speed Networks
I. Public Access to Scholarly Research

IA. Public Access to Federal and

\section{Foundation Funded Research}

Public access to the scientific literature has grown significantly in recent years. Figure XIV lists the major initiatives in the world by funders and national governments to provide access. Some provide access immediately upon publication in a journal and others provide access after a delay of up to one year. The largest depository is NIH's PubMed Central. Should the Federal Research Public Access Act (FRPPA) be enacted by Congress, publications arising from research funded by all federal agencies that fund more than $\$ 100$ million per year in research would ultimately become available to the public for free (Figure XIV).

The volume of material accessed through PubMed is quite significant. The users come from the academy, industry and the general public (Figure XV).

The call to permit public access to articles that otherwise would be available only to those with subscriptions or in institutions with subscriptions has been intense and enduring. The greatest concern express by scholarly journals has been that making their articles public, even after a lag of 12 months, would damage their revenue streams. The NIH repository has been in operation over five years and during that time no major scientific journal has gone out of business or reduced the number of issues or articles published. Financial analysts that follow commercial publishers have concluded that NIH policy has not caused a substantial number of journal cancellations. The good health of the scientific scholarly journal market is unfor- 
tunately evident as seen by the fact that STEM journal prices keep going up.

Physics is the field with longest OA archiving tradition dating back to 1991 . Most physicists report that they go first to arXiv to find their scientific literature, not to the journals. Despite this access preference, the major physics journals say no journal cancelations have resulted from this archive that contains the most important contributions to physics; two physics journal publishers even have their own mirror versions of arXiv. IB. Public Access Deposit Requirements by Universities

Fifty-two research funders worldwide mandate that researchers publicly archive publications arising from their funding. Figure XVI lists those funders.

Universities have begun to "mandate" that their faculty members publicly archive their journal research publications. While "mandate "is the term utilized, it is a misleading term because the universities participating have created mandates as a result of faculty action, not by administratively dictating faculty action. This is strong evidence that faculty are beginning to understand the need for such openness. In the US, the first university-wide mandate was by the faculty at MIT, followed closely by the faculty at the University of Kansas and at Duke. Harvard University is often thought of as being the first U.S. University to create a mandate but that mandate was not university-wide, instead it was by the faculty of Arts and Sciences. Since then faculty of other colleges at Harvard have issued similar mandates but at this writing the mandates do not cover all faculty at Harvard. Worldwide, 149 universities have mandates in place. Other universities in the U.S. and throughout the world have such mandates under consideration.

The first institutional mandate was not by universities or funding agencies but by the U.S. government. Its mandate is different from that of universities as it does not require that publications of federal employees be placed in a repository, but it forbids those employees from giving exclusive copyrights to publishers of their work (see Title 17 United States Code section105). The federal government is ultimately the copyright holder of their work and has the right to publish that work itself even if it has been published in a scholarly journal. Thus the federal government could "publish" all works of employees by placing them in a publicly accessible repository if it chose to do so.

\section{IC. Open Access Journals}

A powerful way of creating public access is for the journal of publication to make all of its articles available to the public for free. As of July 2012 there are 7,902 scholarly journals that follow this practice. The most prominent journals in this group are those published by the Public Library of Science where the editorial boards of the journals frequently have multiple Nobel Prize winners serving on them. Some of the journals are financed by requiring authors to pay publication fees, others are financed by scientific institutions and some are financed by donated funds. The number of OA journals is growing at a very rapid rate (Figure XVII).

\section{ID. Digital Repositories by Universities, Disciplinary Societies}

The most prominent way to make researchers' scholarly works available to 
the public is for disciplinary groups or universities to create digital archives into which such works can be voluntarily deposited. Figure XVIII lists the numbers of such archives that have been created by country and by discipline. Such archives are generally available to search engines, making works placed in them easily available world-wide. In addition to materials voluntarily placed in such archives, some categories of materials such as master's and doctoral theses may be placed there as a result of a university mandate.

The Advantage to the Author of Open or Public Access: Regardless of the vehicle that makes an article publicly accessible, the robust finding is that articles that are publicly accessible are generally cited more frequently than those that can be accessed only through subscriptions. In a major review of 31 studies, Alma Swan writing in 2010 found that 27 of the 31 found a citation advantage for Open Access articles. ${ }^{7}$ Interestingly, physics articles that are placed in arXiv are cited five times more frequently than those that are not and $20 \%$ of the citations actually occur before the article appears in a journal. ${ }^{8}$

There is also evidence that practitioners and even members of the general public wish to access scientific studies and do access them when they have the opportunity to do so. For example, mental health practitioners sent links to articles variously open access and gated. One week later the open access article was found to have been read twice as often. ${ }^{9}$ Six out of ten physicians change their initial diagnosis based on information accessed on line. ${ }^{10}$

\section{Open Research Data}

While there is not widespread agreement among individual researchers that research data should be shared, there is considerable U.S. and international official recognition that it should be. For example, the OECD in supporting open research data concludes that Open Research Data reinforces Open Scientific Inquiry by:

- Encouraging diversity of analysis and opinion

- Promoting new research \& making possible testing of new or alternative hypotheses and methods of analysis

- Supporting studies on datacollection methods and measurements

- Facilitating the education of new researchers

- Enabling the exploration of topics not envisioned by the original investigators

- Permitting the creation of data sets when data from multiple sources are combined. ${ }^{11}$

According to Britain's Royal Society, "the potential of the Internet to facilitate collaboration among both professional and amateur scientists may pave the way for a second open science revolution as great as that triggered by the creation of the first scientific journals." They argue that this highly desirable end is dependent on routine publication of datasets in intelligible, assessable and usable formats which it calls "intelligent openness." Such publication would:

- allow a new breed of data scientists to search for unsuspected relationships, such as between disease 
mechanisms and the properties of drug-like compounds.

- improve the detection of scientific error and,

- help to build public trust in science in areas such as climate science and genetic modification.

Finally and controversially, they argue that this sharing of data sets would be facilitated if high-quality and publicly accessible datasets were to be given as much credit as standard publications in Britain's research excellence framework. ${ }^{12}$

Both the NSF and NIH require researchers they fund to release research data to other researchers (details in Figure XIX). Their requirements lack definition and enforcement at this point but since the requirements are backed by law, one can be sure enforcement eventually will follow.

The development of norms among individual researchers that they should share research data not developed with federal funding is spotty. IPSCR at the University of Michigan is a respected repository for social and political scientists to share data and other such vehicles exist. Most journals have a policy about data sharing to verify research results and some journals simply require that the data on which an article is based be deposited with them.

A growing body of research demonstrates that publicly accessible data bases produce the same sorts of results one gets from publicly accessible journal articles, i.e., they are used more. For example, Heidi Williams considered the follow-on results from the Human Genome Project's open human genome vs. the Celera Corporation's closed one.
Celera sequences were available only to those who paid for them, but Human Genome Project's sequences were publicly available. The Celera-sequences genes led to about 30\% fewer articles about genotype-phenotype links than did the Human Genome projects, demonstrating that public data is used more. She found similarly reduced numbers of diagnostic tests based on Celera articles and increased numbers based on the HGP. ${ }^{13}$

\section{Open Research Organisms and Materials}

Use of genetically identical animals and materials with common properties is essential for generalization of research. Some such organisms/materials are available from open sources maintained by governments/ foundations/ universities and others are available from sources that see them as a revenue source. Just as with scholarly research and data, researchers find that organisms/materials from open sources produce greater benefits than those from closed sources. Two examples:

\section{Mice from Open source vs. Closed source} mice

- Research based on open mice generated substantially more follow-on research and greater "horizontal extension" of follow-on research.

- Research based on open mice is more likely to be found in applied research journals suggesting that the open mice research might lead to faster commercialization. ${ }^{14}$

Biological Resource Center materials vs. Commercial Sourced materials

- Articles based on openly accessible materials got $220 \%$ more citations 
than those based on commercially sourced materials.

- When materials moved from private archives (closed source) to BRCs (open source), citation rates to articles increased 50 to $125 \% .{ }^{15}$

\section{High Speed/Capacity Computing} V. High Speed Networks

I will say little about these two because little needs to be said. Clearly without the super-computer centers funded by NSF over several decades, all but the wealthiest universities would have been without access. While the cost of high speed computing has fallen massively, the need for greater speed and capacity continues to present itself. Problems like global modeling of climate demand more and more capacity and speed. The availability of publicly accessible cutting edge computing will permit low resourced universities to continue to be competitors in all areas of research.

Similarly, Federal funding agency support for high speed networks enabled university research. The development of various communal university institutions continues to permit both public and private universities to enjoy access to what is now a necessity. Such "public access" must continue in the future or the more poorly funded actors will be unable to compete.

\section{Concluding Comments}

My argument is simply that the information infrastructure required to compete in the research environment of the next decades will be less affordable to public research universities than to others because of their financial disadvantages. They would therefore differentially benefit if information infrastructure were made publically available to all without regard to financial factors. Making such resources available in this manner is good for science and for society.

From this argument I proceeded to examine the state of availability of three elements of the information infrastructure: the scholarly literature, research data and research organisms and materials. Much progress has been made in making these information infrastructure elements publicly available. Scientific gain has resulted; much more progress is needed. It is clearly in the interest of public research universities to advocate for that progress and to act on their own campuses to make the elements under their control publicly available.

\section{References}

1. "Politicization of Science in the Public Sphere, A Study of Public Trust in the United States", 1974 to 2010 Gordon Gauchata, University of North Carolina, Chapel Hill, American Sociological Review April 2012 vol. 77 no. 2 167-187

2. Lave, Rebecca; Mirowski, Philip; Randalls, Samuel. 2010. "Introduction: STS and Neoliberal Science." Social Studies of Science 40:659_ 75 .

3. Isaac Newton, Letter to Robert Hooke, February 5, 1675

4. Jeffery L. Furman and Scott Stern, "Climbing Atop the shoulders of Giants: The Impact of Institutions on Cumulative Research" The American Economic Review 101 (5), 2011

5. Barbara J. Culliton, Published online before print March 2006, doi:

10.1377/hlthaff.25.w94"Extracting Knowledge From Science: A Conversation With Elias Zerhouni" Health Affairs, May 2006 vol 25 no 3 w94-w103

6. Robert K. Merton, "The Matthew Effect in Science," 159 Science 56-63 (1968).

7. http://eprints.ecs.soton.ac.uk/18516/2/Citation _advantage_paper.pdf, 2010

8. Gentil-Beccot, Mele and Brooks, CERN, 2010

9. Hardesty Journal of Clinical Psychology (2008)

10. Letter of Francis Collins at http://publicaccess.nih.gov/Collins_reply_toPitts121611.pdf 
11. 2007 OCED Recommendations Concerning Public Access to Research Data from Public Funding

12. "Science as an Open Enterprise: Open Data for Open Science,"

http://www.insidehighered.com/news/2012/06 /22/royal-society-wants-britain-see-equalvalue-datasets-and-journalarticles\#ixzz1yWkXHwAz
13. Heidi Williams. NBER working paper $\# 16123$

14. Murray. et.al. in The Rate and Director of Inventive Activity, Univ. of Chicago Press (forthcoming 2012)

15. Furman and Sterns, American Economic Review $08 / 2011$

\section{Figures:}

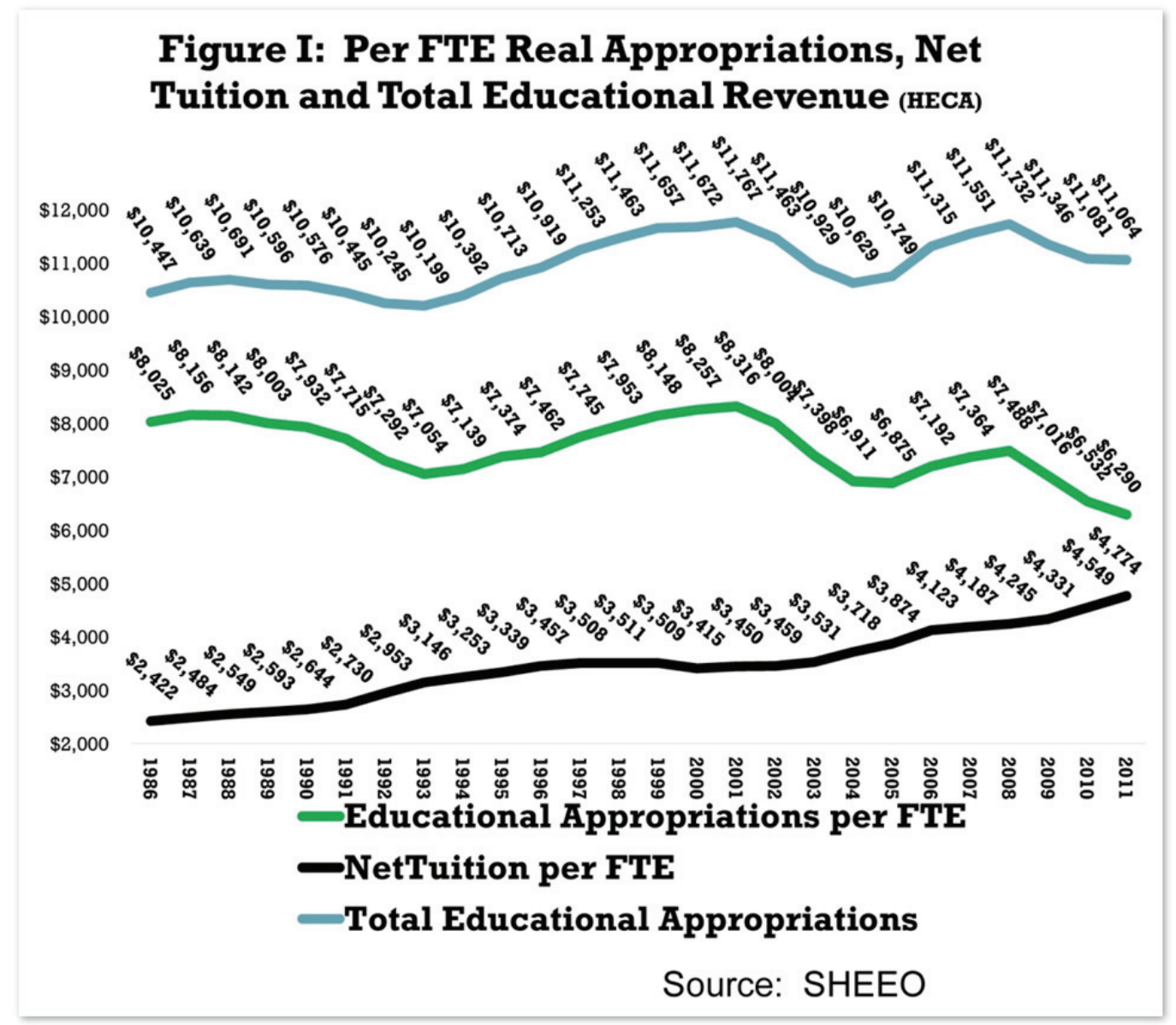




\section{Figure II: State and Local Real, Per Student Appropriations}

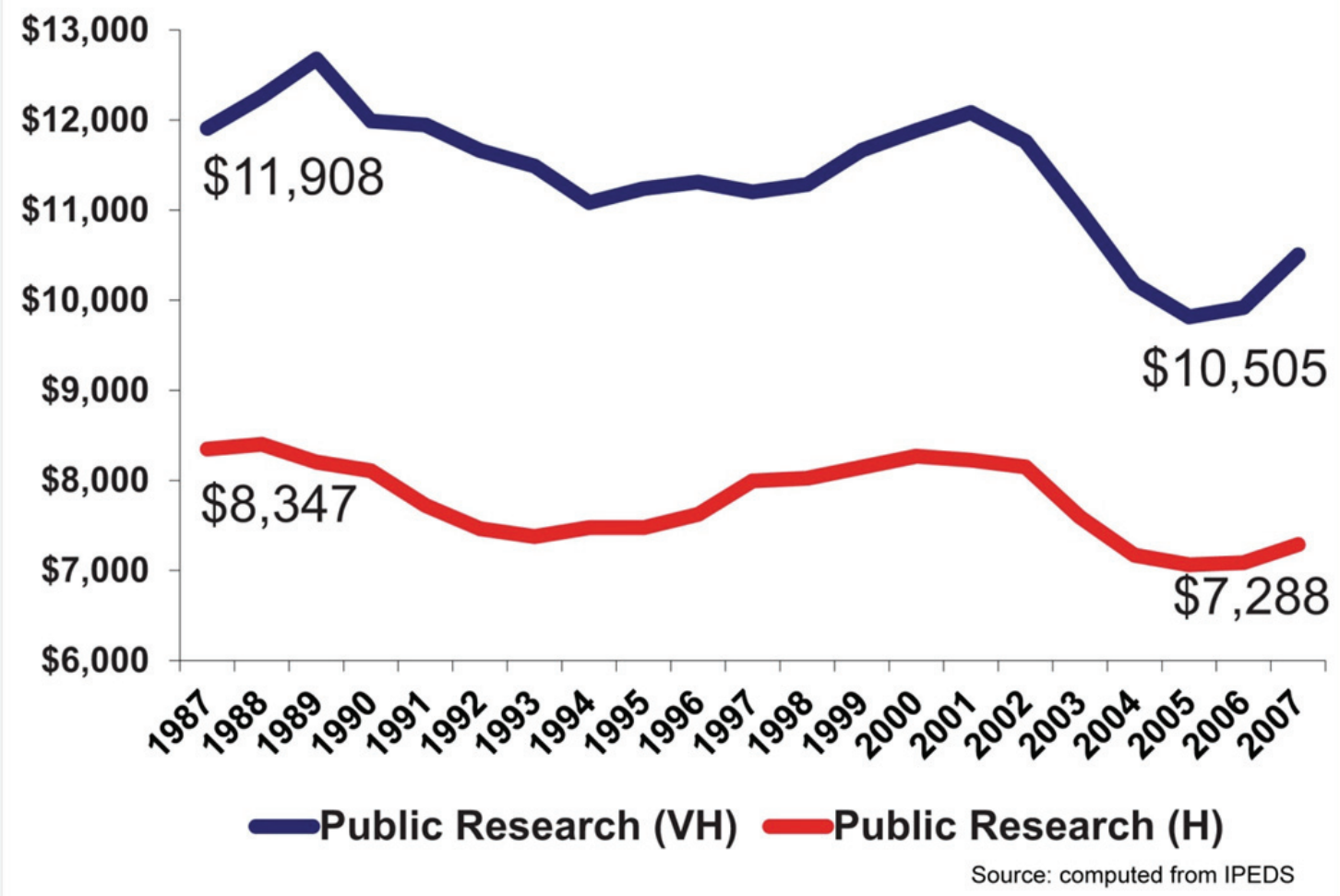

Figure III: The Competition for State Funding is Fierce

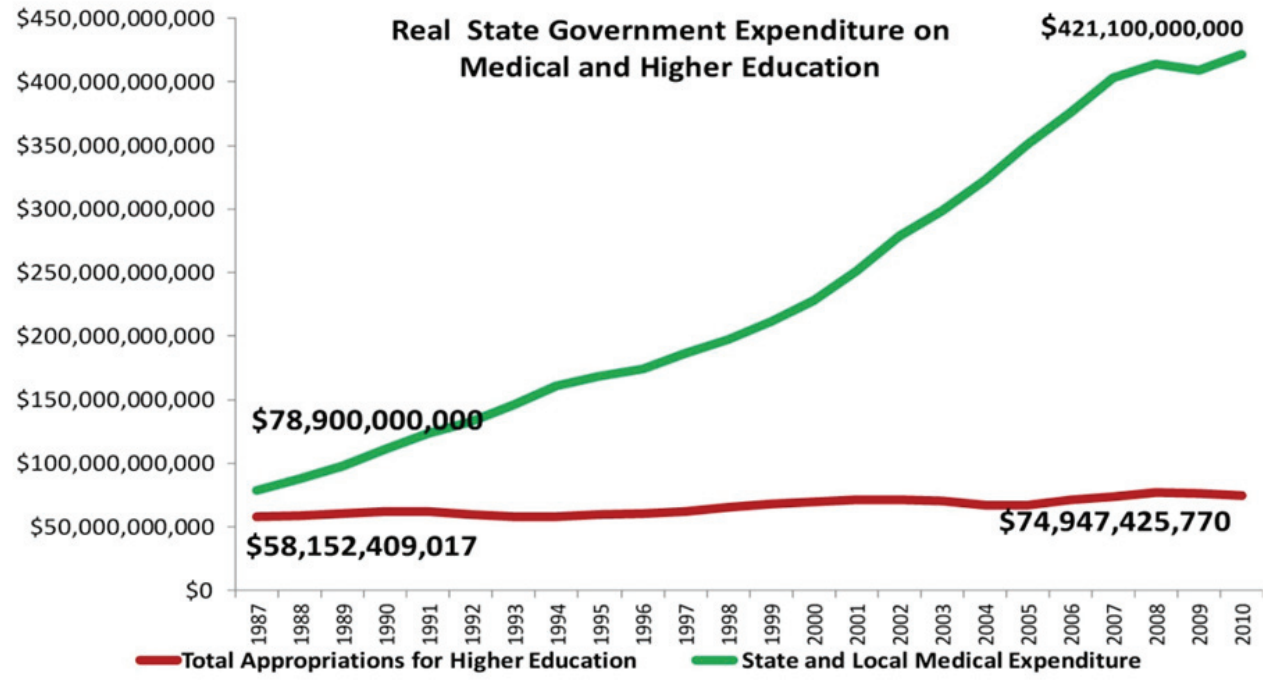

source: Government Spending.com 
Figure IV: Public Universities spend less than half as much per FTE student as private research universities.

Increase in Real Education and Related Expenses Per FTE

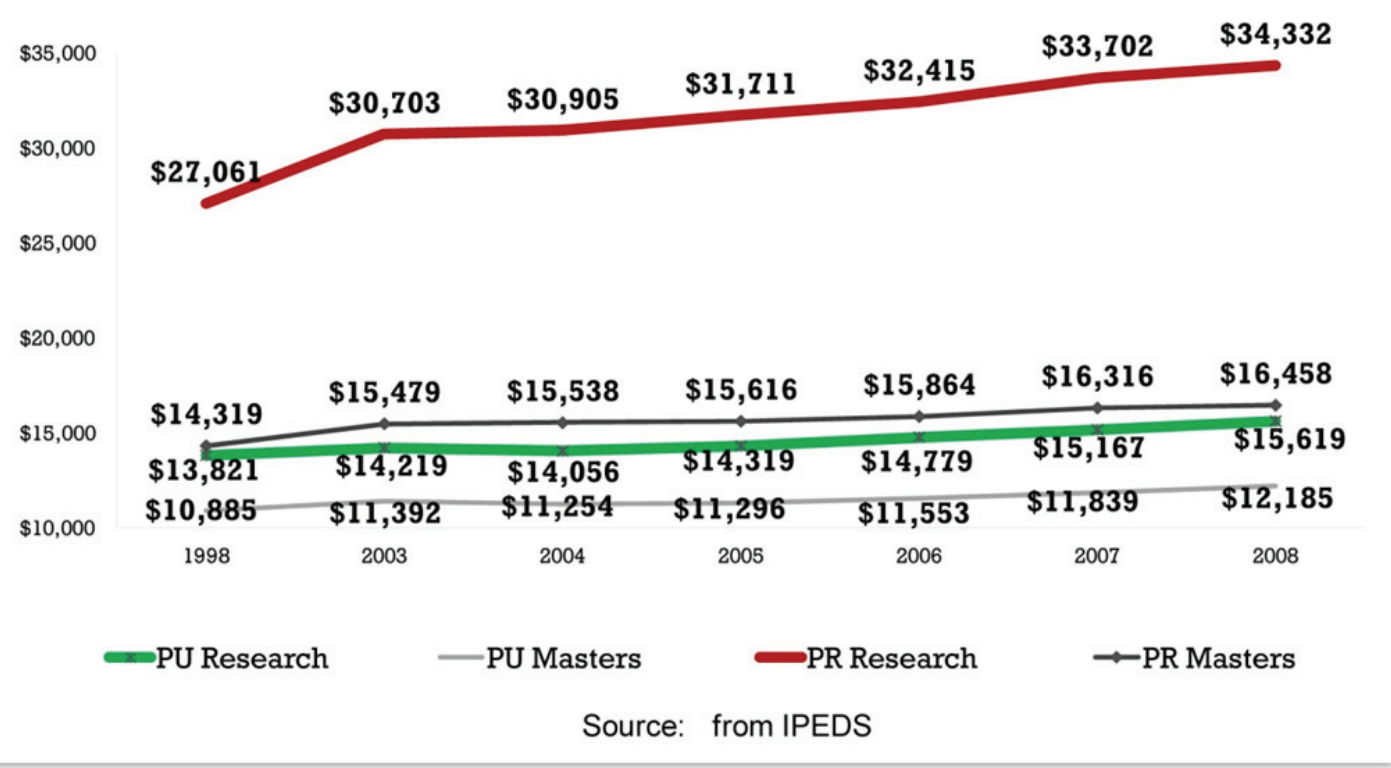

Figure V: Average 9-month Salaries of full-time Faculty in Various Carnegie Categories as a Ratio of those in Private Doctoral Universities

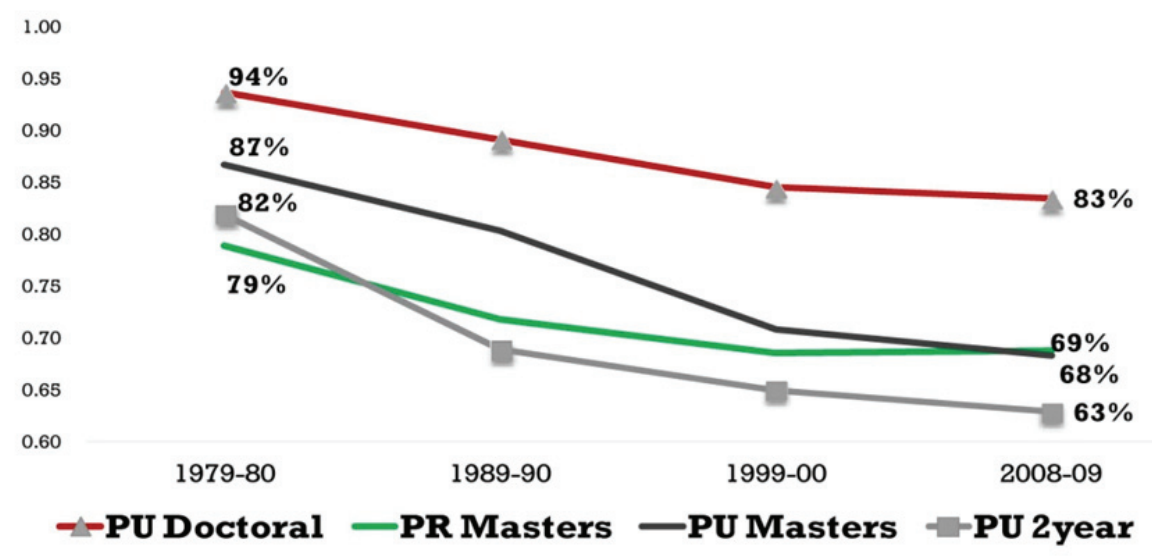

Source: NCES, The Condition of Education 2010, Indicator 44. 


\section{Figure VI: Ratio of Instructional Staff per 100 Students at Public and Private Universities}

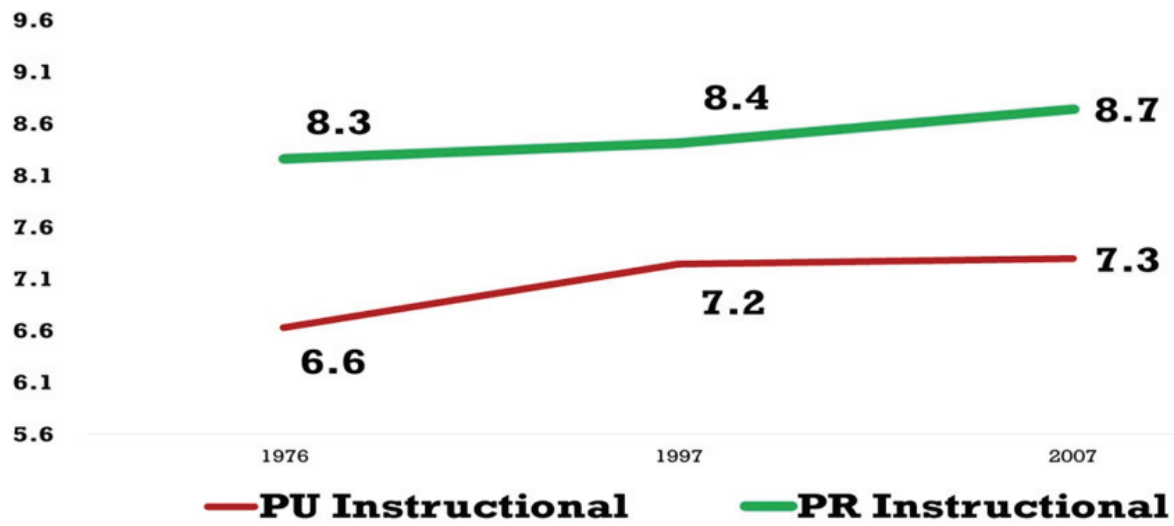

Source: NCES, Digest of Education Statistics 2009, Table 244.

Figure VII: The Tune at Public Universities is increasingly being called by students.

45.00\% Percent of Research University Educational Expenditures from Tuition

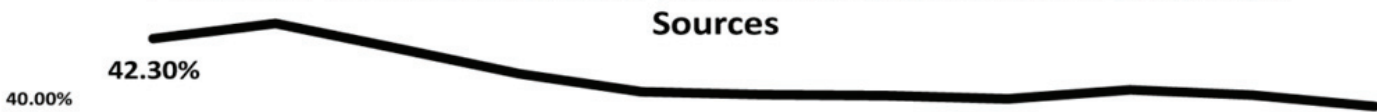

$35.00 \%$

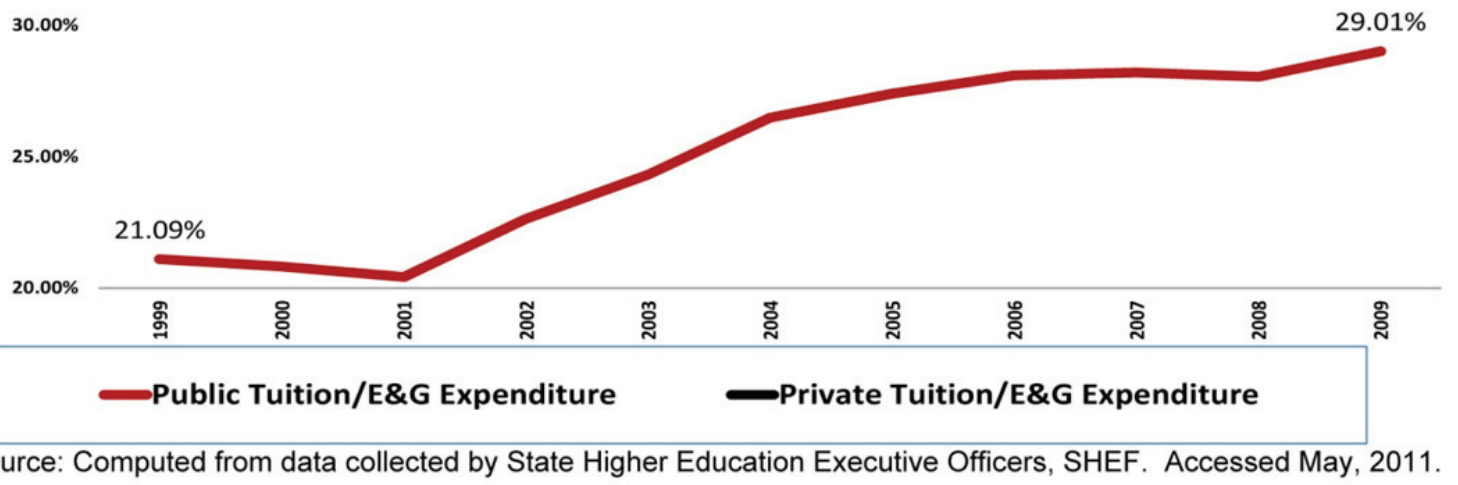

Source: Computed from data collected by State Higher Education Executive Officers, SHEF. Accessed May, 2011. 
Figure VIII

\section{Library Expenditure as a Per Cent of University E\&G Expenditure}

\begin{tabular}{l}
$3.50 \%$ \\
\hline $3.30 \%$ \\
\hline $3.10 \%$ \\
\hline $2.90 \%$ \\
\hline $2.70 \%$ \\
\hline $2.50 \%$ \\
\hline $2.30 \%$ \\
\hline $2.10 \%$ \\
\hline $1.90 \%$ \\
\hline $1.70 \%$ \\
\hline $1.50 \%$ \\
\hline
\end{tabular} $3.41 \%$

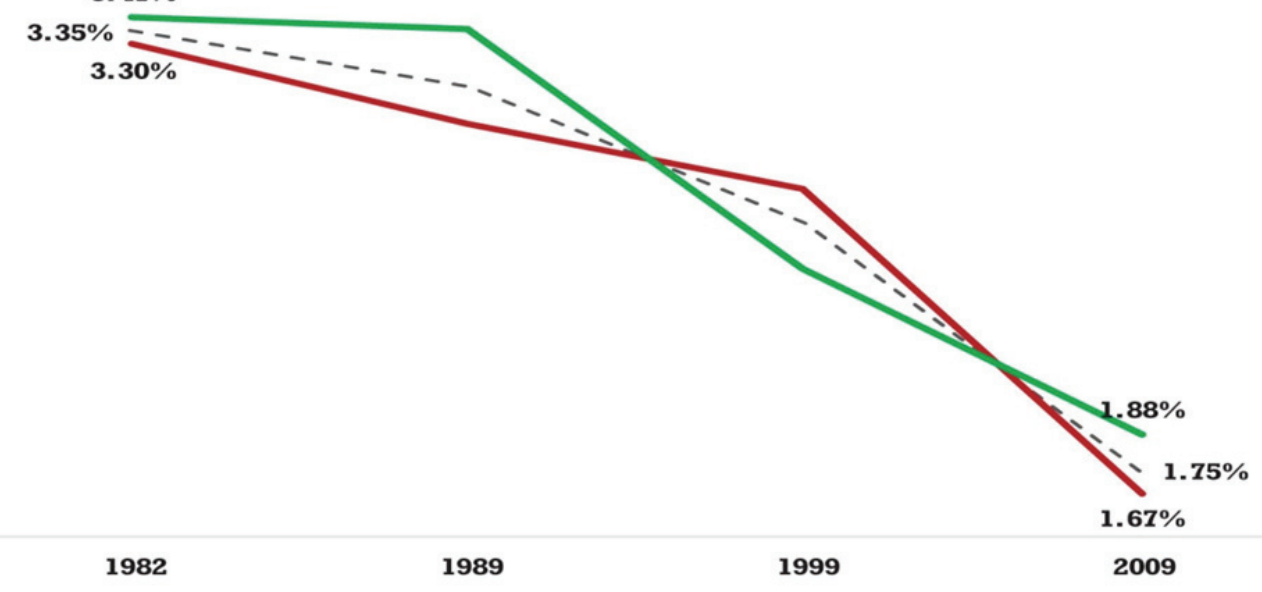

- All Public Private

Source: Computed from ARL data base on Member Library Funding

Figure IX: The academy has steadily increased the subsidy it provides for research with its own funds and public universities subsidize research more heavily than do private universities. Institutionally Funded Research as a Proportion of Federally Funded Research

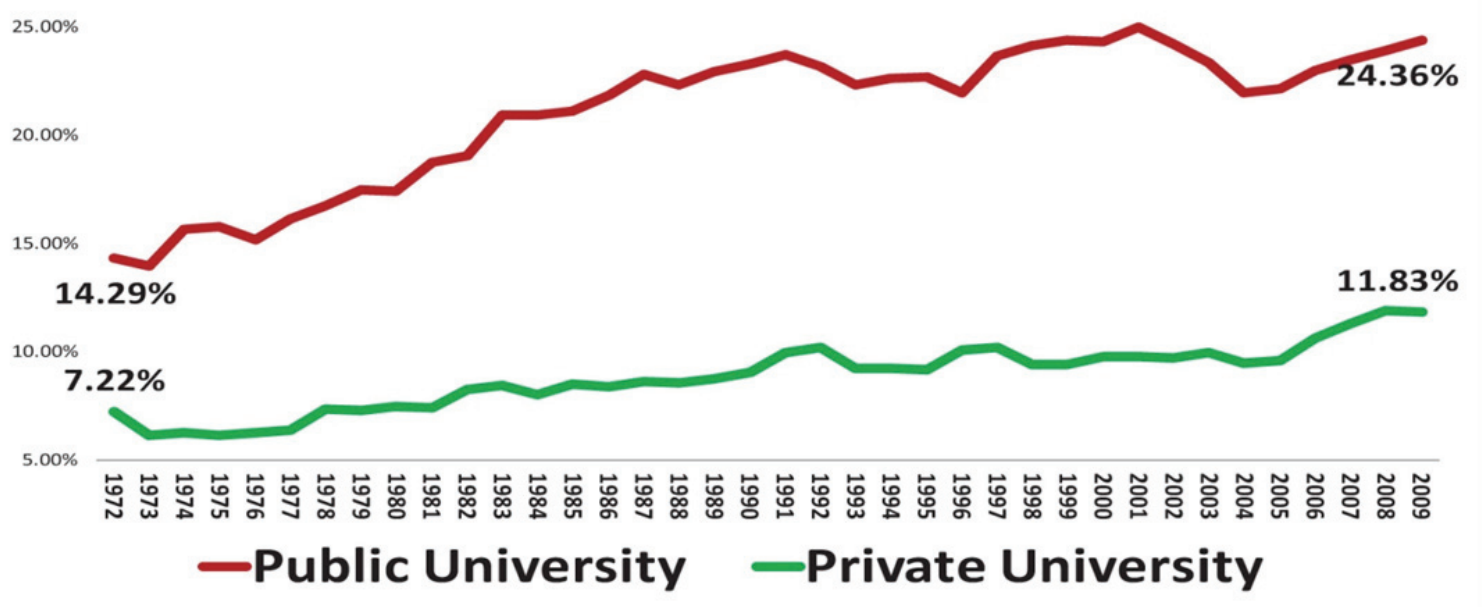


Figure X: Despite the adverse developments, public universities have maintained their competitiveness for federal grant awards but given the increasing discrepancy in faculty salaries, staffing levels and the ever larger subsidy of external research, can this success continue?

Proportion of Federally Financed University Research by Control of University

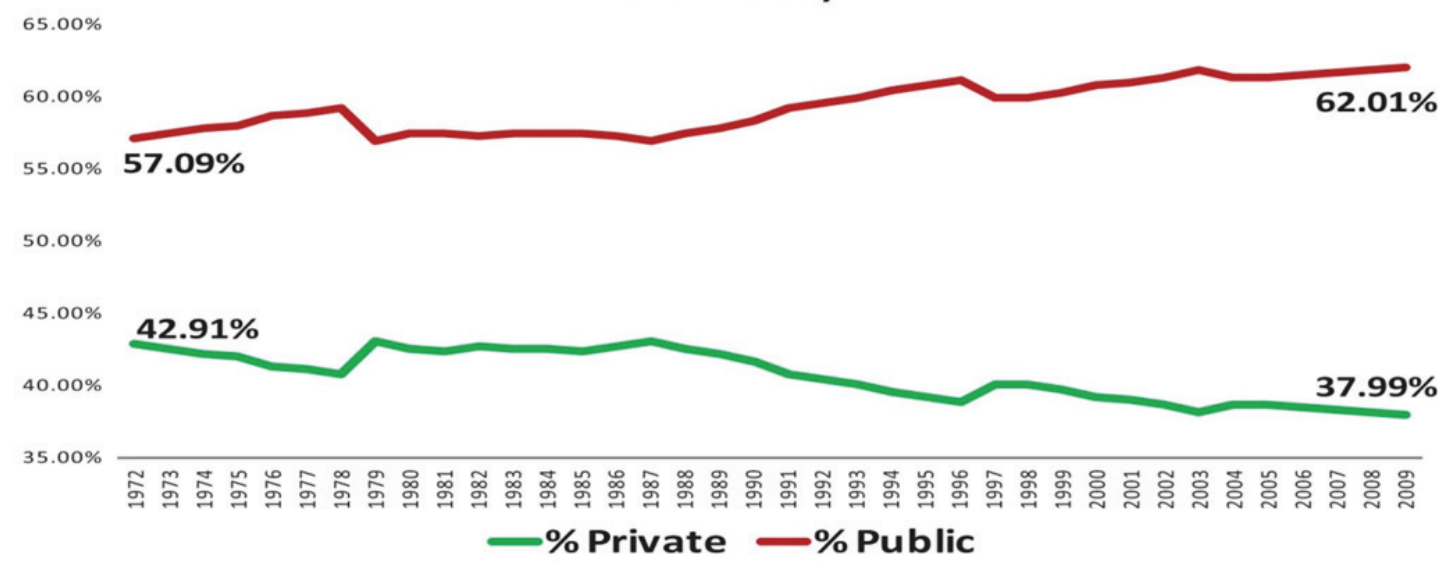

Source: NSF Research Expenditures

\section{Figure XI: Since 2000 Federal Expenditure on R\&D Performed by Industry has far Outpaced that Performed by all Others}

Federal Spending on R\&D, by Performer (in billions)

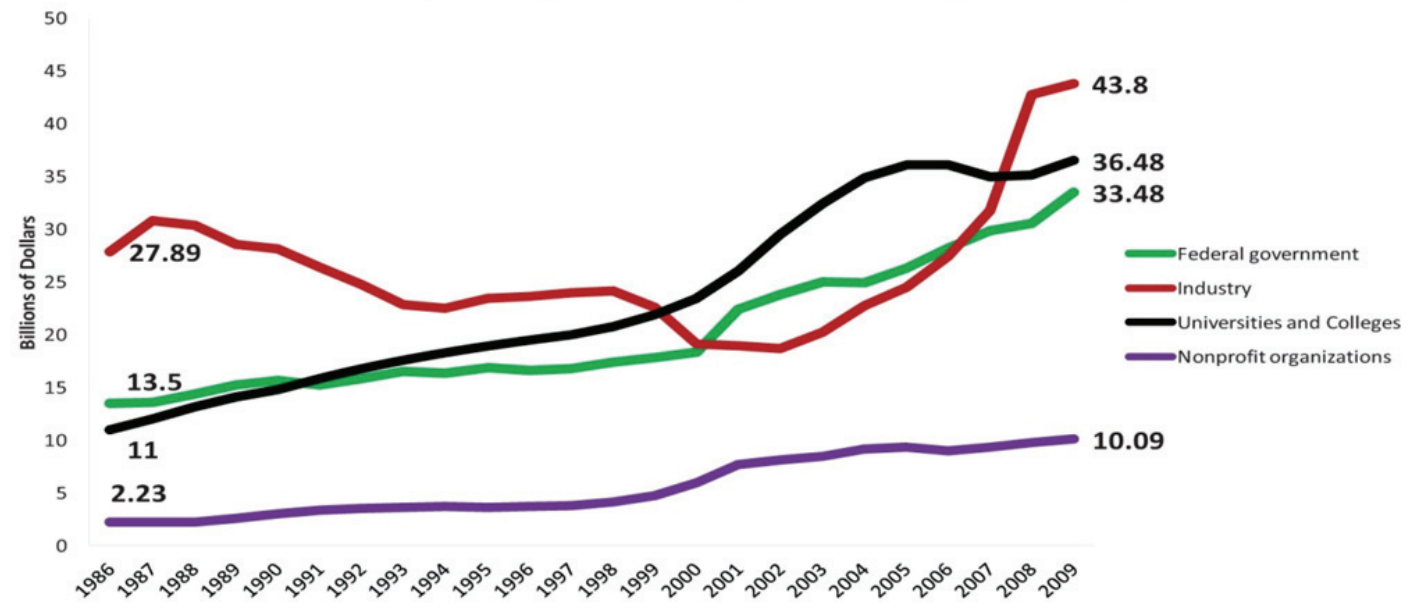


Figure XII: Unadjusted Means of Public Trust in Science for Each Survey Year by Political Ideology

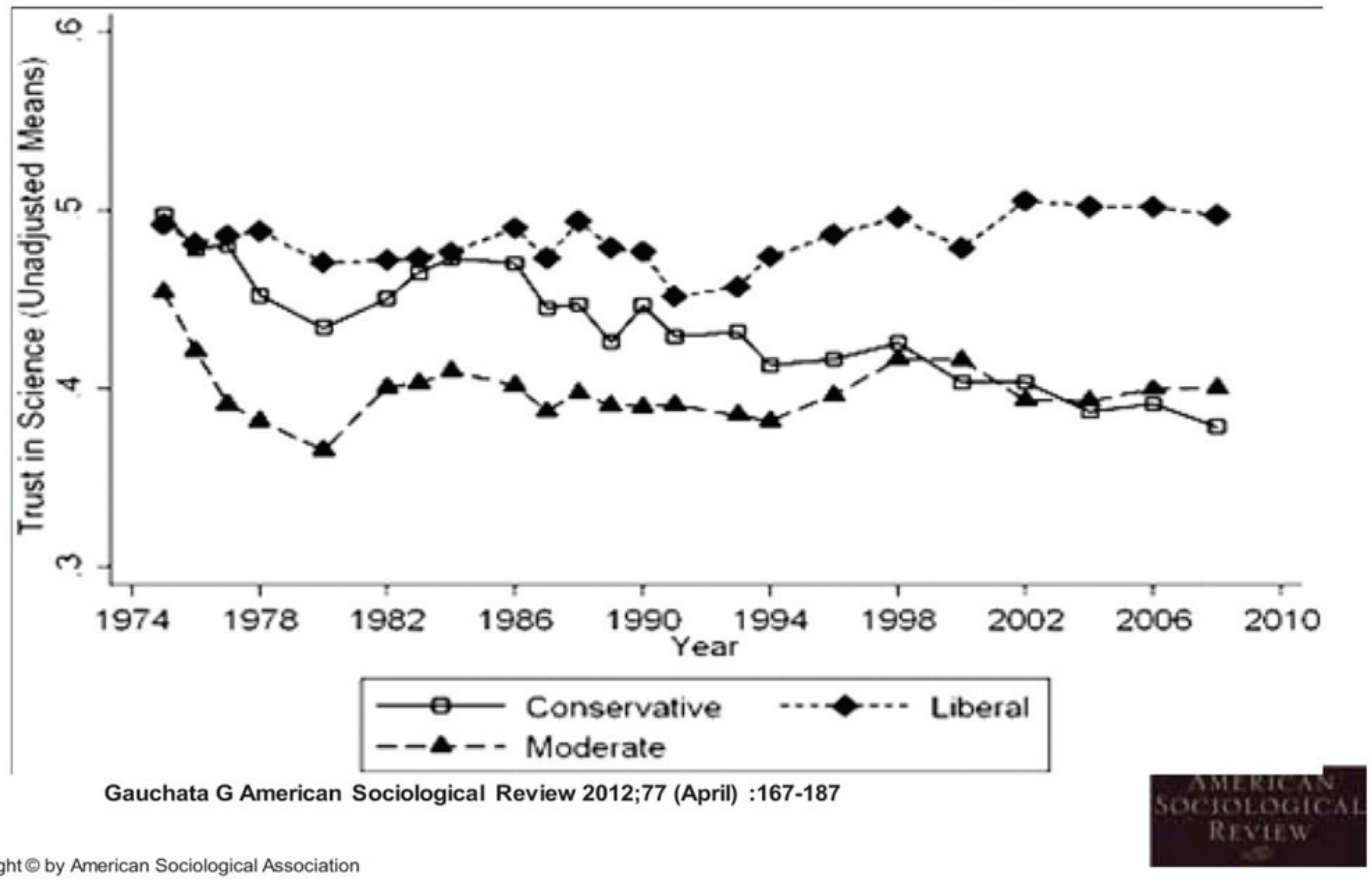




\section{Figure XIII: NRC Research Universities and the Future of America Recommendations}

1. The federal government should adopt stable and effective policies, practices, and funding for university-performed R\&D and graduate education.

2. States should provide greater autonomy for public research universities so that these institutions may leverage local and regional strengths to compete strategically and respond with agility to new opportunities.

3. Increase university cost-effectiveness and productivity.

4. Strengthen the business role in the research partnership, facilitating the transfer of knowledge, ideas, and technology to society, and accelerate "time-to-innovation."

5. Create a Federal Strategic Investment Program that funds initiatives at research universities critical to advancing education and research in areas of key national priority.

6. The federal government and other research sponsors should strive to cover the full costs of research projects.

7. Federal and State governments should reduce or eliminate regulations that increase administrative costs, impede research productivity, and deflect creative energy without substantially improving the research environment.

8. Improve the capacity of graduate programs to attract talented students by addressing issues such as attrition rates, time-to-degree, funding, and alignment with both student career opportunities and national interests.

9. Secure for the United States the full benefits of education for all Americans, including women and underrepresented minorities, in science, mathematics, engineering, and technology. 10. Ensure that the United States will continue to benefit strongly from the participation of international students and scholars in our research enterprise.

\section{Figure XIV: Status of Public Access}

* European Commission is funding Publishing and the Ecology of European Research (PEER) to investigate effects of depositing authors' peer-review manuscripts in a freely accessible location. Action in 2012

* British Government announced intention in Dec. 2011 to require all public funded scientific research be published in OA Journals

* Howard Hughes, Wellcome Trust require deposit of articles

* NIH has required deposit in PubMed Central since April, 2008, of articles emerging from research they support. Contains 21 million citations. 26,000 articles deposited each month.

* 930 journals automatically provide full content

* 300 additional journals provide final, published NIH articles

* 1620 journals provide individual articles.

FRPPA is now in Congress with 35 bi-partisan congressmen signed on. Principal Republican co-sponsor is Kevin Yoder of Kansas. FRPPA would expand an $\mathrm{NIH}$-like requirement to all federal funding agencies with more than $\$ 100$ million annually in research grants 


\title{
Figure XV: The Volume of Access due to PubMed is Huge
}

\author{
* Pub Med access is 500,000 on typical weekday. \\ * 1 million+ articles downloaded each day \\ - $25 \%$ visitors from academic institutions \\ - $40 \%$ visitors from general public \\ - $17 \%$ visitors from companies
}

\section{Figure XVI: Funder Mandates - 52 World-Wide}

Agency Nationale de la recherche (ANR) (Humanities and Social Sciences Branch) (29 Jul 2008)

Arthritis Research UK (04 Jan 2007)

Arts and Humanities Research Council (AHRC) (06 Sep 2007)

Australian Research Council (06 Dec 2006)

Autism Speaks (13 Nov 2008)

Biotechnology and Biological Sciences Research Council (BBSRC) (23 Jul 2006)

British Heart Foundation (BHF) (09 Jan 2007)

Canadian Breast Cancer Research Alliance (CBCRA) (02 Oct 2007)

Canadian Breast Cancer Research Alliance (CBCRA) (28 Jun 2009)

Canadian Cancer Society (CCS) (01 Oct 2008)

Canadian Health Services Research Foundation (CHSRF) (23 Apr 2009)

Canadian Institutes of Health Research (CIHR) (04 Jan 2007)

Cancer Research UK (09 Jan 2007)

Chief Scientist Office (Scottish Executive Health) (CSO) (09 Jan 2007)

Department of Health (UK) (DoH) (09 Jan 2007)

EUR-OCEANS Consortium on Ocean Ecosystem Analysis (21 Mar 2011)

Economic and Social Research Council (ESRC) (23 Jul 2006)

Engineering \& Physical Sciences Research Council (EPSRC) (04 Oct 2011)

European Commission - 2 (EC) (20 Aug 2008)

European Research Council (ERC) (04 Jan 2007)

Fonds de la recherche en sante Quebec (FRSO) (05 Feb 2009)

Fonds zur Foerderung der wissenschaftlichen Forschung (FWF) (09 Oct 2006)

Government of the Principality of Asturias (06 Feb 2009)

Health Research Board (Ireland) (HRB) (16 Feb 2008)
Heart and Stroke Foundation of Canada (05 Jul 2010) Howard Hughes Medical Institute (HHMI) (02 Oct 2007) Hungarian Scientific Research Fund (OTKA) (22 Jul 2009) Institute of Education Sciences (25 Jun 2009)

International Development Reseach Centre (IDRC) (13 Jul 2011) Irish Higher Education Authority (HEA) (22 Aug 2008)

Irish Research Council for Science, Engineering \& Technology (IRCSET) (18 Sep 2007) JISC (Joint Information Systems Committee) (02 Oct 2007)

Madrid Autonomous Community of Spain (CM) (28 Mar 2009)

Medical Research Council (MRC) (23 Jul 2006)

Michael Smith Foundation for Health Research (MSFHR) (23 Aug 2009)

National Health and Medical Research Council (NHMRC) (09 Dec 2006)

National Health and Medical Research Council (NHMRC) (22 Feb 2012)

National Institutes of Health (NIH) (25 Dec 2007)

National Research Council (NRC) Canada (16 Jul 2008)

Natural Environmental Research Council (NERC) (16 Aug 2006)

Norwegian Research Council (05 Feb 2009)

Ontario Institute for Cancer Research (OICR) (27 Jun 2008)

Research Foundation Flanders (FWO) (07 Apr 2007)

Science Foundation Ireland (SFI) (18 Feb 2009)

Science and Technology Facilities Council (STFC) (20 Oct 2006)

Spanish General State Administration (16 May 2011)

Swedish Research Council Formas (25 May 2010)

Swedish Research Council Vetenskapradet (15 Oct 2009)

Swiss National Science Foundation (SNF) (10 Aug 2007)

Telethon Italy (01 Mar 2010)

The Dunhill Medical Trust (26 Jul 2011)

Wellcome Trust (23 Jul 2006) 
Figure XVII: 7902 OA Journals in the World (6/25/2012), Wide-spread Geographically, In all Disciplines

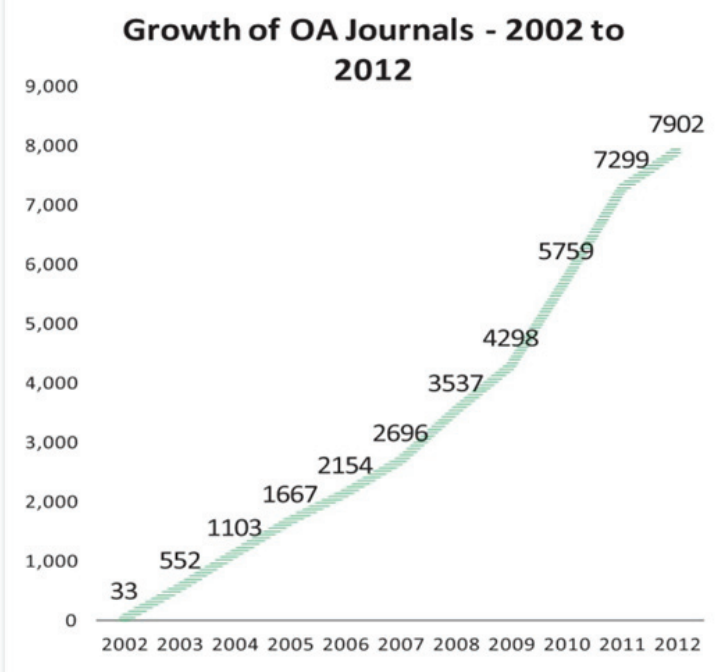

\begin{tabular}{|c|c|}
\hline \multicolumn{2}{|c|}{$\begin{array}{c}\text { Countries with more than } \\
100 \text { OA Journals }\end{array}$} \\
\hline United States & 1231 \\
\hline Brazil & 743 \\
\hline United Kingdom & $\underline{543}$ \\
\hline India & $\underline{414}$ \\
\hline Spain & 414 \\
\hline Egypt & 315 \\
\hline Germany & $\underline{248}$ \\
\hline Canada & $\underline{238}$ \\
\hline Romania & $\underline{228}$ \\
\hline Italy & 210 \\
\hline Turkey & 198 \\
\hline Colombia & 183 \\
\hline France & 154 \\
\hline Iran & 141 \\
\hline Chile & 139 \\
\hline Poland & 133 \\
\hline Argentina & 124 \\
\hline Mexico & 120 \\
\hline Australia & 119 \\
\hline New Zealand & 109 \\
\hline Switzerland & 106 \\
\hline Japan & 106 \\
\hline
\end{tabular}

\section{Figure XVIII: Repositories are Distributed World Wide and Across Many Disciplines}

\begin{tabular}{|l|l|}
\hline & $\begin{array}{l}\text { \# of Institutional } \\
\text { Repositories }\end{array}$ \\
\hline US & 388 \\
\hline UK & 206 \\
\hline Japan & 137 \\
\hline China & 33 \\
\hline India & 54 \\
\hline Australia & 48 \\
\hline Germany & 149 \\
\hline France & 66 \\
\hline Brazil & 62 \\
\hline
\end{tabular}

\begin{tabular}{|l|l|}
\hline & $\begin{array}{l}\text { \# of Disciplinary } \\
\text { Repositories }\end{array}$ \\
\hline Biology & 98 \\
\hline Chemistry & 62 \\
\hline Math & 67 \\
\hline Physics & 62 \\
\hline Medicine & 195 \\
\hline CS/IT & 113 \\
\hline Geology & 114 \\
\hline History & 170 \\
\hline Business/Econ & 130 \\
\hline Education & 106 \\
\hline Multidisciplinary & 1,339 \\
\hline
\end{tabular}

http://www.opendoar.org/ 


\section{Figure XIX: NSF and NIH "Require" Data Sharing}

- As required by 45 CFR part 74.36, grantees that are institutions of higher education, hospitals, or non-profit organizations must release research data first produced in a project supported in whole or in part with Federal funds that are cited publicly and officially by a Federal agency in support of an action that has the force and effect of law

- NSF Investigators are expected to share with other researchers, at no more than incremental cost and within a reasonable time, the primary data, samples, physical collections and other supporting materials created or gathered in the course of work under NSF grants. Grantees are expected to encourage and facilitate such sharing. NSF Data Management Plan Requirements - Proposals submitted or due on or after January 18,2011 , must include a supplementary document of no more than two pages labeled "Data Management Plan". This supplementary document should describe how the proposal will conform to NSF policy on the dissemination and sharing of research results.

- NIH believes that data sharing is essential for expedited translation of research results into knowledge, products, and procedures to improve human health. $\mathrm{NIH}$ endorses the sharing of final research data to serve these and other important scientific goals and expects and supports the timely release and sharing of final research data from $\mathrm{NIH}$ supported studies for use by other researchers. "Timely release and sharing" is defined as no later than the acceptance for publication of the main findings from the final data set. All investigator-initiated applications with direct costs of $\$ 500,000$ or more (excluding consortium F\&A costs) in any single year are expected to address data-sharing in their application. 